\title{
Leading collaboratively
}

\section{Rob Worrall, Consultant in Strategic Leadership at the National School of Government in Scotland, looks at how public service leaders in Scotland are maximising HR value during the economic downturn...}

$\mathbf{F}$ rom the smoking ban to stem cell research, the Scots are not afraid to take the lead. In another first, through the Scotland Performs website, the public can monitor the progress of the government's ambitious economic strategy, which harnesses the collaborative potential of the whole of the public service to 'focus on the difference that we make and not just the inputs or processes over which we have control' (Scottish Government, 2008a).

There is official recognition that things need to be done differently, with an underpinning philosophy of creating public value supported by developing collaborative leaders who are able to work across organisational and sectorial boundaries (Elvidge, 2006, Moore, 1995). This renewal of the public service ethos, and a deliberate and courageous return to the distinctive 'publicness' of public services, goes beyond delivering a transactional output towards transforming the way services are designed and delivered so that they achieve '...tangible improvements in the things that matter to the people of Scotland' (Scottish Government, 2008a; 2008b).

\section{And....and...}

A focus on value for money and performance management is important for improving public services, but not enough to deliver the next stage of the Public Service Reform Agenda (Thomas, 2009). The fallout from the ongoing economic debacle means that as the public purse progressively tightens, public value thinking has a growing resonance, especially given the need to try and rebuild levels of public trust in government and service delivery (IDeA, 2009).

Where activities have not made the intended difference, we will need to co-create more innovative approaches to delivery. It is not a choice of 'and/or' between effectiveness and efficiency, but 'and/and' with increasing effectiveness through collaboration creating greater efficiencies in the longer term (Maddock, 2008).

\section{Leadership for a new era - evolution not revolution}

So what are the implications for public service leaders in Scotland? And how can Human Resources Development (HRD) support public service leaders to meet these challenges head on?

Firstly, we need to improve our understanding of what the implications of applying public value theory to shaping public service delivery are for leadership development. Evidently, some of this work is ongoing; for example, the collaborative leadership initiatives being led by the Scottish Government. But how deep is the level of understanding both within sectors and across agencies at the local level? In assessing the value of applying public value and the implications for public service leaders, Mager (2007) notes that core competences that will need to be developed include:

- Building coalitions of interest with key local partners around a clear focus or priority;

- Navigating complex 'authorising environments' and handling implications for governance and accountability;

- Developing organisational culture and capacity to be more responsive to the outcomes of consultations and deliberations;

- Managing the political sensitivities of consultation including determining when to lead and shape public preference and when to respond;

- Increasing senior leaders' visibility and carrying out processes in a very open manner.

Secondly, for public service leaders, it is also a case of 'and/and' - we cannot always make a choice between being transactional (managing and maintaining the status quo) and being a transformational leader. The latter may sound and feel sexier, but the operational day job still has to be done. However, the more successful leaders will be those who have the capability (and wider environmental awareness) to be able to switch between operating as a single cell and coming together to create a dynamic organism, which is more effective than the sum of its parts. They will be able to engage and inspire their followers to go that extra mile and exceed expectations. 
The key differences between transactional and transformational leaders (BBC, 2009)

\begin{tabular}{|l|l|}
\hline Transactional Leader & Transformational Leader \\
\hline $\begin{array}{l}\text { Conditional reward } \\
\text { Contracts exchange of } \\
\text { rewards for effort, promises } \\
\text { rewards for good } \\
\text { performance, recognises } \\
\text { accomplishments }\end{array}$ & $\begin{array}{l}\text { Charisma } \\
\text { Provides vision and sense of } \\
\text { mission, instils pride, gains } \\
\text { respect and trust }\end{array}$ \\
\hline $\begin{array}{l}\text { Management by } \\
\text { exception (active) } \\
\text { Watches and searches } \\
\text { for deviations from rules } \\
\text { or standards, takes } \\
\text { corrective action }\end{array}$ & $\begin{array}{l}\text { Inspiration } \\
\text { Communicates high } \\
\text { to foctations, uses symbols } \\
\text { important purposes in } \\
\text { simple ways }\end{array}$ \\
\hline $\begin{array}{l}\text { Management by } \\
\text { exception (passive) } \\
\text { Intervenes only if standards } \\
\text { are not met }\end{array}$ & $\begin{array}{l}\text { Intellectual stimulation } \\
\text { Promotes intelligence, } \\
\text { rationality and careful } \\
\text { problem-solving }\end{array}$ \\
\hline $\begin{array}{l}\text { Laissez-faire } \\
\text { Abdicates responsibility, } \\
\text { avoids making decisions }\end{array}$ & $\begin{array}{l}\text { Individualised consideration } \\
\text { Gives personal attention, treats } \\
\text { each employee individually, } \\
\text { coaches and advises }\end{array}$ \\
\hline
\end{tabular}

Thirdly, public service leaders will increasingly need to operate collaboratively in the 'space in-between', outside the traditional hierarchical organisation-bounded authority. The traditional 'chalk and talk' still has a role in effective leadership development, and there is considerable scope and strength in developing leadership skills within an organisation or sector-based context. But this is not enough in itself. There needs to be an increased focus on how to solve real problems, working through them together with leaders from across different sectors using tools such as collaborative enquiry and action learning.

Collaboration does not lie just off 'easy street'. Research on successful collaborative leaders has identified key skills such as patience, tenacity, coalition-building, empathy, building trust, and being able to hold difficult conversations (Archer \& Cameron, 2009). It is often the softer skills that are the hardest to apply, and that can only be honed experientially, and by drawing on the lessons from 'doing.' Collaboration is hard to do, so when deciding to go into partnership, you need to be hardheaded and be clear about what is in it for you, and what is in it for other people. You will need to build a coalition or support network, both those who are supportive and those who can act as a critical friend. Collaborative leaders achieve with other people.

\section{The key role of HRD}

HRD has a key strategic role to play in supporting the development of public service leaders who are comfortable, capable and confident at leading collaboratively across organisation and sectorial boundaries.

Firstly, we need to work more closely with leaders and be clearer about what contribution leadership development can be expected to make to the wider public service reform agenda and to achieving the desired outcomes at local level. There needs to be a better balance between individual and team development, on the one hand and cross-sector interventions (which foster multi-agency approaches and strengthen the understanding of how to deliver outcomes through partnership) and whole systems leadership development on the other.

Secondly, we need to help leaders develop understanding of the challenges faced by their peers in other sectors and the wider policy and service delivery environment. This could be developed through increasing interchange, but also by articulating an expectation that senior leaders gain experience in the wider public, private and not-forprofit sectors.

Thirdly, HR professionals need to be developing their own networks and alliances into active collaborations working with colleagues and practitioners to co-create and deliver collaborative leadership development interventions, especially where there is a shared responsibility for delivering key outcomes.

Finally, whilst the issues faced by Scotland have to be understood within their particular context, there are similar challenges in other parts of the UK. Collaborative leadership development initiatives have been developed and delivered, and new ones are being piloted through the Public Service Leaders Alliance (PSLA) for example. Scotland's public sector is set fair to give a new lead - in leadership and collaboration - but there is also considerable scope to share its experience and also learn from what is happening elsewhere.

\section{References}

Archer D \& Cameron D (2009). Collaborative Leadership: How to succeed in an interconnected world, Butterworth-Heinemann, Oxford

BBC (2009). Women as Leaders. Accessed, 15th May 2009: www.open2. net/moneyandmanagement/world_work/women_leaders.html

Elvidge J (2006). Written evidence to Audit Committee - Auditor General for Scotland 'How Government Works' reports, Scottish Government, January IDeA (2009). New routes to better outcomes, IDeA, London (Draft Publication) Lendrum T (2007). The Strategic Partnering Handbook: Building Strategic Partnerships and Alliances, McGraw Hill, North Ryde, Australia

Maddock S (2009). Change You Can Believe In: The Leadership of Innovation, National School of Government, Sunningdale Park

Mager C (2007). 'Public Value and Leadership: Exploring the implications', Centre for Excellence in Leadership, 1-12

Moore M H (1995). 'Creating Public Value: Strategic Management in Government', Harvard University Press, MA, USA

Public Services Leaders Alliance (2009). Draft Manifesto (not yet published), London Scottish Government (2008a). Outcomes Approaches 'Working' Guidance for Public Sector Bodies, Scottish Government, September.

Scottish Government (2008b). Scotland Performs goes live, Scottish Government, 2nd June, 1-1: www.scotland.gov.uk/News/Releases/2008/06/02090043

Thomas A (2009). Innovation - you have to be prepared to take a risk, Public Servant, 18-19th May

\section{Contact:}

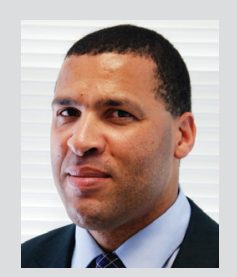

Rob Worrall Consultant in Strategic Leadership National School of Government, Scotland Tel: $+44(0) 1344634240$ rob.worrall@nationalschool.gsi.gov.uk www.nationalschool.gov.uk/scotland 